\title{
POTENSI INDUSTRI “KERIPIK ENYE” DALAM PENINGKATAN KESEJAHTERAAN MASYARAKAT DESA WALURAN KABUPATEN SUKABUMI
}

\author{
Indra Griha Tofik Isa ${ }^{1^{*}}$, Iwan Rizal Setiawan ${ }^{2}$, Dicky Jhoansyah ${ }^{3}$ \\ ${ }^{1}$ Teknik Informatika, Universitas Muhammadiyah Sukabumi, igtiku@gmail.com \\ ${ }^{2}$ Teknik Informatika, Universitas Muhammadiyah Sukabumi, myfrank@gmail.com \\ ${ }^{3}$ Administrasi Bisnis, Universitas Muhammadiyah Sukabumi, dicky.jhoansya@gmail.com
}

\begin{abstract}
ABSTRAK
Abstrak: Desa Waluran merupakan desa penyangga yang ada di Kawasan Wisata Geopark Ciletuh. Dengan dekatnya Desa Waluran Mandiri pada Objek Wisata Geopark Ciletuh belum memberikan kontribusi perekonomian dalam peningkatan kesejahteraan masyarakat. Padahal di daerah ini terdapat industri "Keripik Enye" yang dapat diangkat menjadi potensi lokal yang dapat menarik perhatian turis Geopark Ciletuh. Bahan baku yang melimpah yakni Singkong banyak dijumpai di Desa Waluran, sehingga terdapat 3 sentra pabrik pembuat enye yang rata-rata produksinya dari 100 kg singkong mentah menghasilkan $38 \mathrm{~kg}$ "Keripik Enye". Pabrik Enye ini memiliki sejumlah pekerja yang seluruhnya merupakan warga asli Desa Waluran. Pekerja Pabrik Enye didominasi perempuan usia rata-rata 25-40 tahun dan hanya mengandalkan penghasilan di Pabrik Enye tersebut. Permasalahan yang dihadapi adalah secara umum masyarakat belum menyadari bahwa "Keripik Enye" khas Waluran dapat diangkat menjadi produk potensi daerah yang dapat menarik minat para turis yang akan berwisata ke Geopark Ciletuh. Untuk menunjang hal tersebut maka dilakukan (1) inovasi produk; (2) promosi media online dengan YouTube dan Instagram; (3) pengurusan Perizinan Industri Rumah Tangga (P-IRT); (4) Kerjasama dengan Dinas Pariwisata Kabupaten Sukabumi. Sehingga hasil akhir yang didapatkan adalah terjadi peningkatan penjualan dan produk "Keripik Enye" menjadi dikenal sebagai produk lokal khas Waluran.
\end{abstract}

Kata Kunci: Produk Potensi Lokal, Peningkatan Kesejahteraan, "Keripik Enye",

Abstract: Waluran Village is one of buffer village in Geopark Ciletuh tourism area. With proximity to Geopark Ciletuh tourism area, it has not given economic contribution in improving community welfare. Even though in this area there is "Keripik Enye" Home Industry which can be appointed as local potential for attracting attention Ciletuh Geopark Tourists. The abundant raw materials that is Cassava, can be found in Waluran Village, so that there are 3 center of "Keripik Enye" Home Industry which produces $38 \mathrm{~kg}(\mathrm{~s})$ from $100 \mathrm{~kg}$ of raw Cassava in everyday. The workers of "Keripik Enye" Home Industry is dominated by women in 25 to 40 average years and only rely on working in Home Industry "Keripik Enye". The general problem which faced by people in Waluran Village is they do not realize that Waluran's "Keripik Enye" could be adopted as local potential product which can attract to the tourists who traveled to Ciletuh Geopark. Things which are done to solve the problems are (1) Doing product innovation; (2) Accompaniment in online promotion; (3) Accompaniment in Licensing of Home Industry; (4) Cooperation to Government tourism office of Sukabumi District. The results of this action are the growth of sales product and "Keripik Enye" is known well as Waluran's local potential product.

Keywords: Local Potential Product, welfare improvement, "Keripik Enye" 


\section{A. LATAR BELAKANG}

Kabupaten Sukabumi merupakan Kabupaten terluas kedua di Pulau Jawa setelah Kabupaten Banyuwangi dengan luas wilayah sebesar $4.161 \mathrm{~km}^{2}$ atau 11,21\% dari luas Jawa Barat [5]. Kabupaten Sukabumi memiliki potensi alam yang beragam dengan masyarakat yang majemuk dan secara administratif memiliki 47 Kecamatan[4]. Dari sisi perekonomian, lingkup pekerjaan masyarakat Kabupaten Sukabumi yang tertinggi adalah dalam bidang Pertanian, Kehutanan dan Perkebunan dengan bobot persentasi sebanyak $23,35 \%$ dan sisanya terbagi kedalam sektor jasa, kontruksi, perdagangan besar, dan sebagainya. Hal ini menandakan bahwa beberapa segmen masyarakat Kabupaten Sukabumi sangat tergantung pada sektor Pertanian, Kehutanan dan Perkebunan, dimana salah satunya adalah Kecamatan Waluran dengan 78\% masyarakatnya adalah petani [1], dengan komoditas utamanya adalah Padi dan Singkong. Secara administratif Kecamatan Waluran membawahi 6 Desa yakni: Desa Caringin Nunggal, Desa Mangunjaya, Desa Mekar Mukti, Desa Sukamukti, Desa Waluran dan Desa Waluran Mandiri. Khususnya Desa Waluran yang merupakan Desa penghasil Singkong, menjadikan Desa ini memiliki kelompok tani singkong yang memproduksi produk olahan berupa "Keripik Enye" yang berbahan baku dari singkong. Berikut gambar 1 menunjukkan peta Kecamatan Waluran beserta desa yang melingkupinya [5].

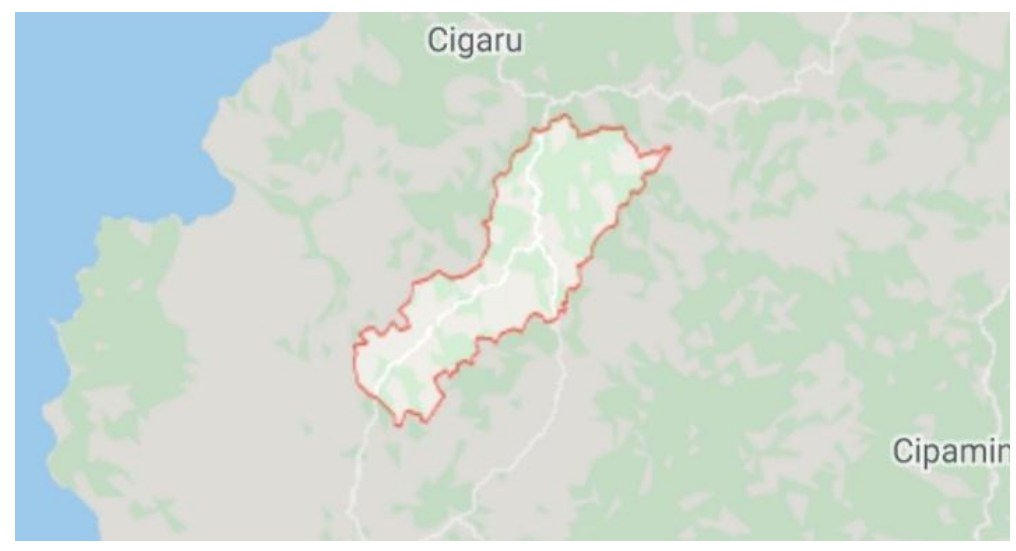

Gambar 1. Peta Wilayah Kecamatan Waluran

Khususnya di daerah Sunda, "Keripik Enye" menjadi salah satu panganan yang digemari di seluruh segmen masyarakat, karena selain murah juga rasanya yang gurih dan enak. Hal lain yang dimiliki "Keripik Enye" Waluran ini memiliki rasa gurih yang berbeda dengan "Keripik Enye" buatan daerah lain, karena berasal dari bahan dasar singkong yang memiliki kualitas terbaik dengan masa panen $8-20$ bulan [2]. Desa Waluran sendiri berada di ketinggian $380-880 \mathrm{mdpl}$ [3], dan ini sangat ideal untuk tumbuhnya tanaman singkong. Sehingga singkong yang dihasilkan di Desa Waluran memiliki perpaduan rasa manis yang pas, yang menyebabkan "Keripik Enye" Khas Waluran memiliki karakteristik gurih 
yang berbeda. Adapun harga jual "Keripik Enye" Khas Waluran berkisar antara Rp 12.000 - Rp 15.000 per kilogram. Pembuatan bahan "Keripik Enye" tidak menggunakan bahan pengawet kimiawi, namun dengan cara dikeringkan pun sudah dapat memperpanjang usia kadaluwarsa [3].

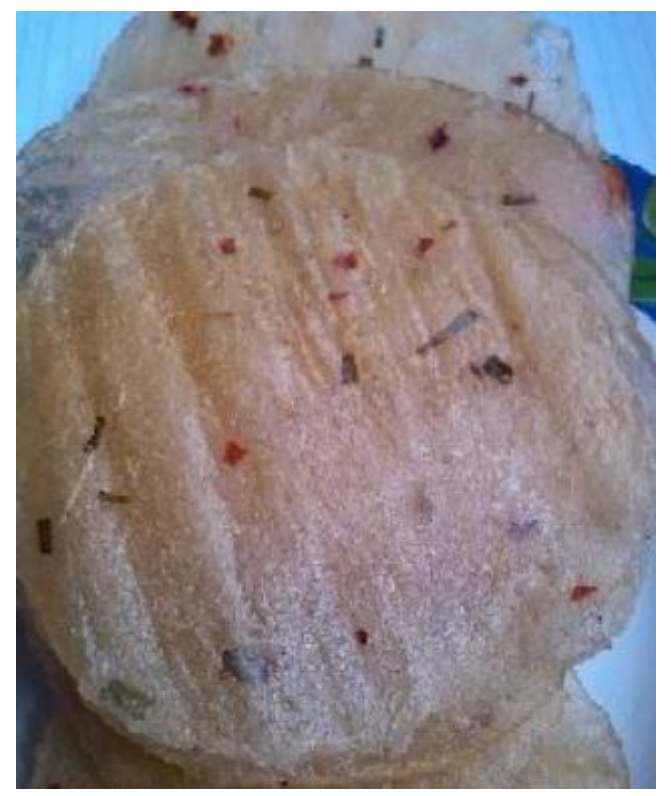

Gambar 2. Sampel "Keripik Enye" Waluran

Permasalahan Permasalahan yang terjadi adalah "Keripik Enye" Khas Waluran ini kurang begitu dilirik oleh masyarakat daerah setempat maupun pemerintah, dalam hal ini pemerintah Desa untuk diangkat menjadi potensi yang dapat "dijual", terutama bagi para pengunjung wisata Geopark Ciletuh. Namun juga berdasarkan fakta di lapangan, terdapat beberapa hal yang spesifik mengapa hal tersebut terjadi:

\section{Kurang Media Promosi}

Hal ini menjadi kendala utama mengapa "Keripik Enye" Khas Waluran kurang begitu terkenal, terutama di sekitar Kabupaten dan Kota Sukabumi. Dengan hanya mengandalkan promosi dari mulut ke mulut oleh para perantau yang membeli "Keripik Enye" ini, tentu belum memberikan hasil yang maksimal. Bila dirata-ratakan penjualan "Keripik Enye" berjumlah 50-80 kg / minggu, dengan produksi Enye bisa mencapai $60 \mathrm{~kg}$ per hari nya. Ini menjadi sebuah permasalahan bila penjualan "Keripik Enye" tidak dilakukan dengan maksimal. Menurut hasil diskusi dengan Ketua Kelompok Tani "BOGASARI", yakni ibu Enay, bahwa dalam 2 tahun terakhir ini mengalami penurunan penjualan produk dan sisa produk "Keripik Enye" yang tidak terjual akan disimpan hingga berjamur dan tidak memiliki nilai jual, sehingga akhirnya "Keripik Enye" tersebut akan dibuang percuma. 


\section{Pengemasan Produk yang Tidak Menarik dan Varian Rasa yang Terbatas}

Setiap pembeli yang membeli "Keripik Enye" Waluran, penjualan dilakukan dengan membungkus produk "Keripik Enye" dengan kantung plastik berwarna hitam. Dari sisi estetika pun dapat disimpulkan bahwa hal ini yang menjadikan "Keripik Enye" waluran kurang begitu dikenal oleh masyarakat diluar Desa Waluran. Tidak dapat dipungkiri bahwa pengemasan yang baik dapat menjadi parameter pembeli untuk memutuskan melakukan pembelian pada produk tertentu. Untuk penjualan keripik dalam skala besar, kantung pembungkusnya berupa karung bekas pembungkus beras. Padahal keripik yang diproduksi ini memiliki kualitas terbaik dengan rasa berkarakter yang merepresentasikan Desa Waluran. Adapun untuk varian rasa masih terbatas dengan rasa original (rasa asin dengan rempah-rempah). Rasa yang masih terbatas tersebut karena produsen "Keripik Enye" belum berani melakukan improvisasi produk.

\section{Belum ada Legalisasi Produk}

Terkadang pembeli akan bertanya bahwa produk tertentu aman untuk dikonsumsi atau tidak. Untuk itulah diperlukan suatu legalisasi produk yang ditetapkan oleh Badan Pengawas Obat dan Makanan. Salah satu perizinan yang harus dimiliki oleh industri rumah tangga seperti ini adalah izin P-IRT. "Keripik Enye" Waluran sendiri belum memiliki izin P-IRT, hal ini berdampak pada sulitnya "Keripik Enye" Waluran berekspansi dinikmati oleh konsumen yang berada diluar Kabupaten Sukabumi dan sekitar Cianjur dan Bogor. Faktor ini juga menyebabkan "Keripik Enye" Waluran kalah saing dengan produsen "Keripik Enye" lainnya. Bahkan yang untuk wilayah Kota Sukabumi dan sekitarnya kecenderungan memilih sejenis "Keripik Enye" yang diproduksi di daerah luar jawa barat, seperti daerah Solo sebagai produsen "Keripik Enye" yang dikemas dengan kemasan menarik dan mencantumkan nomor izin P-IRT.

\section{Pemerintah Daerah Belum Mengetahui Tentang Potensi "Keripik Enye"}

Salah satu tolak ukur keberhasilan industri kecil dan mikro adalah peran serta masyarakat dan pemerintah daerah, dalam konteks ini adalah Pemerintah Desa setempat yakni Pemerintah Desa Waluran. Hal yang terjadi adalah pemerintah Desa Waluran belum menyadari bahwa "Keripik Enye" Khas Waluran dapat diangkat untuk "dijual" kepada para wisatawan yang akan berkunjung ke Geopark Ciletuh. Mengingat pemerintah desa terfokus pada pengelolaan perkebunan karet dan teh. Dengan diangkatnya "Keripik Enye" Khas Waluran ini sebagai salah satu komoditas utama di Desa Waluran, secara tidak langsung juga akan meningkatkan perekonomian warga setempat, seperti yang sudah 
diuraikan sebelumnya bahwa buruh di pabrik pembuat enye ini adalah perempuan usia produktif yang sangat tergantung sekali kepada pabrik enye. Artinya jika penjualan dan pendapatan pabrik menurun, maka akan berimbas pada pendapatan para pekerjanya.

\section{B. METODE PELAKSANAAN}

Dalam kegiatan PKM ini dibutuhkan tahapan yang jelas berupa metode pelaksanaan kegiatan, sehingga tujuan dari PKM tercapai. Adapun gambaran keseluruhan metode pelaksanaan tersebut terdapat pada Gambar 1 di bawah ini:

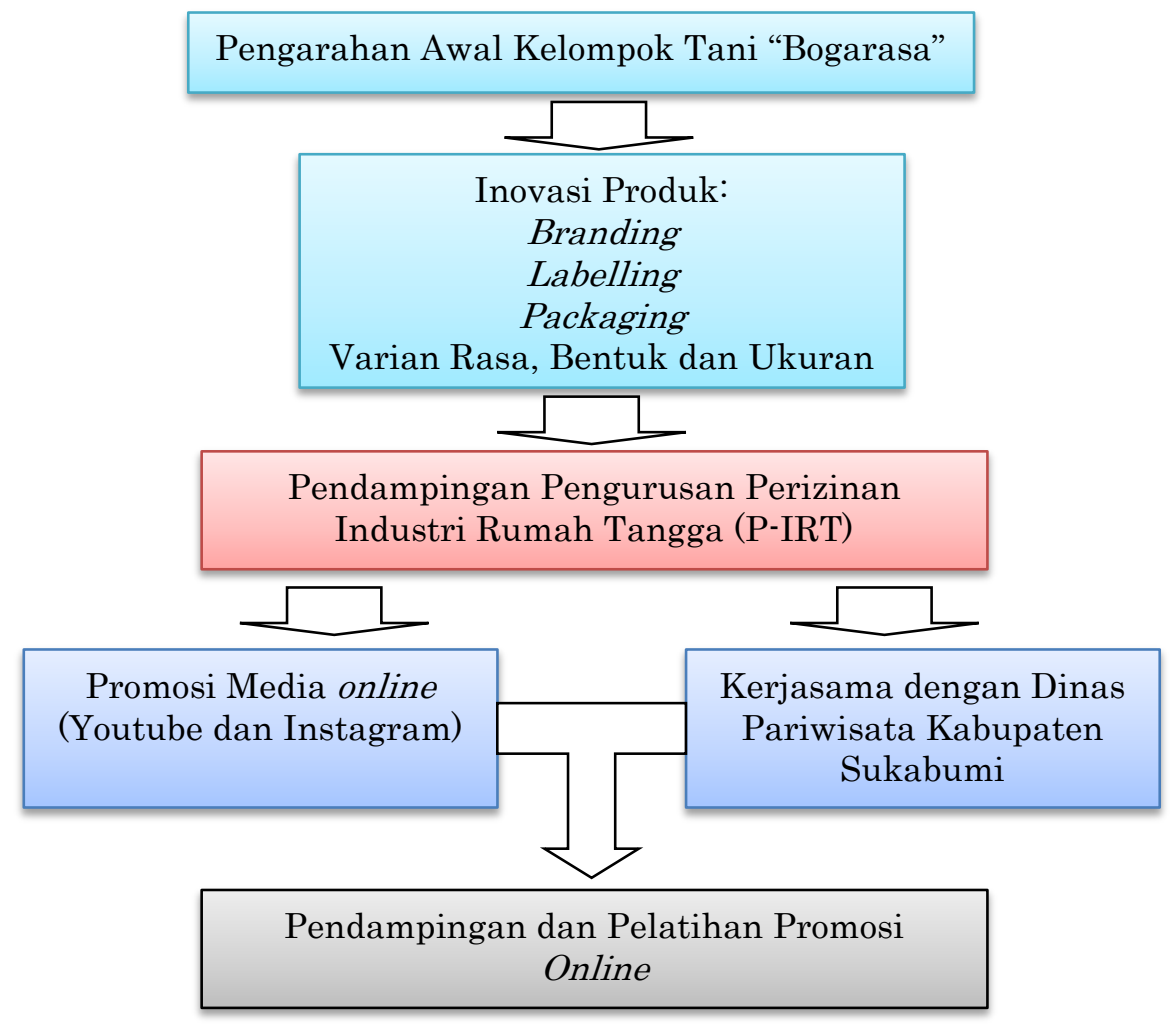

Gambar 3. Metode Pelaksanaan Kegiatan

Berikut penjelasan dari bagan pada Gambar 1 di atas:

\section{Pengarahan Awal Kelompok Tani "BOGARASA"}

Sebagai sosialisasi dari Program Kemitraan Masyarakat yang akan dilaksanakan, maka diperlukan dukungan dari berbagai lapisan masyarakat yang ada di Desa Waluran. Pada kegiatan ini akan mengundang beberapa perwakilan dari masyarakat bahwa PKM Kelompok Tani "BOGARASA" ini akan dilaksanakan dan dilakukan lokakarya awal dengan mengekspos program kerja yang akan dilaksanakan. Adapun beberapa perwakilan masyarakat yang akan diundang adalah:

a. Kelompok Tani "BOGARASA"

b. Perwakilan Kepala Dusun 

c. Perwakilan Karang Taruna
d. Perwakilan Pemerintah Desa Waluran

\section{Pembuatan Produk Sampling}

Ada 4 hal yang akan dilakukan dalam kegiatan ini, yakni menentukan branding, labeling, packaging dan pengembangan produk. Adapun dalam pelaksanaannya akan melibatkan mahasiswa sebagai bagian teknis dan masukan ide kreatifnya yang dikolaborasikan dengan pakempakem yang ada pada Kelompok Tani "BOGARASA", Proses pembuatan produk sampling ini akan dilakukan secara berulang-ulang, untuk memaksimalkan formulasi sampling produk dari sisi pengemasan, bentuk enye, dan varian rasa

\section{a. Branding}

Branding dalam suatu produk diperlukan untuk menunjukan identitas, karakteristik dan konsep produknya. Dalam hal ini, dimana "Keripik Enye" Khas Waluran belum memiliki branding yang kuat. Dengan adanya branding yang kuat dari produk "Keripik Enye" ini, menghasilkan nilai jual yang lebih bagi konsumen. Adapun branding yang dilakukan adalah: (1) Menentukan merek produk yang memiliki nilai jual / marketable; (2) Menentukan tagline yang merepresentasikan "Keripik Enye" Khas Waluran sebagai oleh-oleh yang wajib dicicipi ketika para wisatawan berwisata ke Geopark Ciletuh; (3) Menentukan logo produk yang memiliki nilai filosofis sebagai interpretasi dari "Keripik Enye" Khas Waluran.

\section{b. Labeling}

Setelah konsep branding sudah ada, selanjutnya adalah labeling. Labeling disini adalah menuangkan branding tersebut ke dalam desain kemasan. Dalam tahapan ini diperlukan ide-ide kreatif untuk menuangkan gagasan tersebut. Dari mulai pemilihan huruf, pemilihan warna, bentuk dan ukuran kemasan.

c. Packaging

Kemasan dibuat menggunakan konsep ergonomis yang memiliki sisi estetika yang baik.

d. Pengembangan Produk

Sebagai upaya untuk pengembangan produk sehingga masuk ke dalam segala segmen, selain dari rasa Original, maka akan ditambahkan bumbu pelengkap sebagai varian rasa, dengan tidak mengubah komposisi bahan pembuatan "Keripik Enye". Penambahan varian rasa terdiri 4 rasa yakni: (1) Rasa Keju; (2) Rasa Balado; (3) Rasa Barbeque; (4) Rasa Ayam Bawang. 
3. Pendampingan dan Pendaftaran Perizinan Industri Rumah Tangga ( $\mathrm{P}$ IRT) yang dilakukan kepada Kelompok Tani "BOGARASA".

Materi yang diberikan dalam kegiatan ini adalah:

a. Menjabarkan gambaran Umum P-IRT

b. Pentingnya perizinan dalam pemasaran suatu produk

c. Tata cara dan persyaratan untuk melakukan pendaftaran P-IRT

d. Proses Pendampingan Pendaftaran P-IRT hingga diterbitkannya surat izin PIRT yang dikeluarkan oleh Dinas Kesehatan.

e. Uji laboratorium pangan untuk mengetahui komposisi zat makanan atau nutrisi yang terkandung di dalam "Keripik Enye". Ketika uji laboratorium sudah diketahui, dan direkomendasikan oleh Dinas Kesehatan maka akan dicantumkan dalam kemasan "Keripik Enye"

Dalam pendampingan hingga diterbitkannya surat izin P-IRT, tim Program Kemitraan akan melakukan monitoring dan koordinasi baik kepada pihak Kelompok Tani "BOGARASA" yang dikoordinir oleh Ketua Kelompok Tani, yakni Ibu Enay, maupun pihak yang mengeluarkan izin P-IRT yakni Dinas Kesehatan Kabupaten Sukabumi. Pelaksanaan monitoring dan koordinasi dilaksanakan dalam waktu rentang 1 - 2 bulan, hingga diterbitkannya surat izin P-IRT.

\section{Promosi Media Sosial Instagram dan Youtube}

Kelompok Tani "BOGARASA" secara konvensional sudah melakukan pemasaran, namun hanya "menunggu bola", tanpa melakukan "jemput bola". Pada kegiatan ini Tim PKM akan mengarahkan dalam konsep pemasaran produk dengan media sosial Instagram dan Youtube dengan melibatkan Kelompok Tani "BOGARASA"

5. Kerjasama dengan Dinas Pariwisata Kabupaten Sukabumi Dinas Pariwisata sebagai representasi dari pemerintah dalam pengelolaan Geopark Ciletuh

\section{Pelatihan dan Pendampingan Promosi}

Kegiatan ini bertujuan untuk mengedukasi masyarakat khususnya para pemasar produk "Keripik Enye" Khas Waluran. Dalam kegiatan ini akan melibatkan para pemuda di Desa Waluran yang tergabung dalam Karang Taruna dan tentunya Kelompok Tani "BOGARASA".

\section{HASIL DAN PEMBAHASAN}

\section{Lokakarya Awal}

Kegiatan ini merupakan tahapan awal sebagai bagian dari pengenalan program kerja kepada mitra. Dalam kegiatan ini dijelaskan apa saja program kerja yang akan dilaksanakan yang meliputi:

a. Brainstorming dan Pembuatan Konsep Branding Produk. 
b. Brainstorming Pengembangan produk yang meliputi dimensi "Keripik Enye", varian rasa, inovasi produk

c. Pembuatan logo Produk

d. Sosialisasi kebutuhan Perizinan Industri Rumah Tangga (P-IRT)

e. Pendampingan Registrasi Perizinan Industri Rumah Tangga (P-IRT)

f. Pembuatan akun dan Pendampingan pemasaran online melalui sosial media: Instagram dan Youtube.

g. Kerjasama dengan Dinas Pariwisata Kabupaten Sukabumi dan pihak-pihak yang akan membantu pemasaran produk, seperti komunitas wisata pajampangan dan komunitas wisata Geopark Ciletuh

Adapun peserta lokakarya meliputi perwakilan dari masyarakat yang terdiri dari Pihak Desa yang diwakili oleh Kepala Desa beserta jajarannya, Pihak Kecamatan yang diwakili oleh sekretaris Camat, kelompok tani "BOGARASA" dan pemuda yang tergabung dalam Karang Taruna. Kegiatan Lokakarya ini dilaksanakan pada :

$\begin{array}{ll}\text { Hari / Tanggal } & \text { : Jumat / 29 Maret } 2019 \\ \text { Pukul } & : 09.00-15.00 \\ \text { Tempat Kegiatan } & \text { : Aula Desa Waluran Mandiri }\end{array}$

Hasil dari kegiatan Lokakarya ini adalah masyarakat akan mendukung kegiatan peningkatan industri "Keripik Enye" sebagai potensi lokal yang dapat diangkat dalam mendukung pariwisata pajampangan, khususnya di kawasan Geopark Ciletuh.

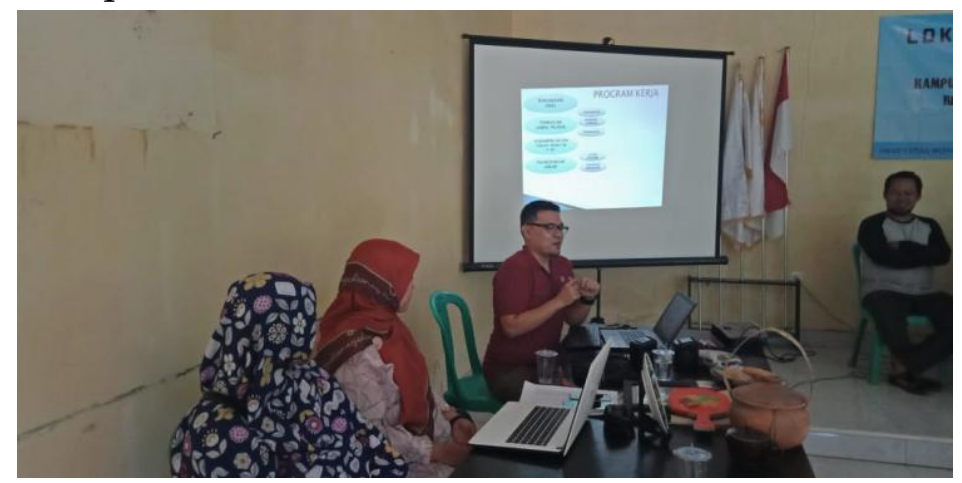

(a) Paparan Program Kerja Kegiatan bersama Mitra

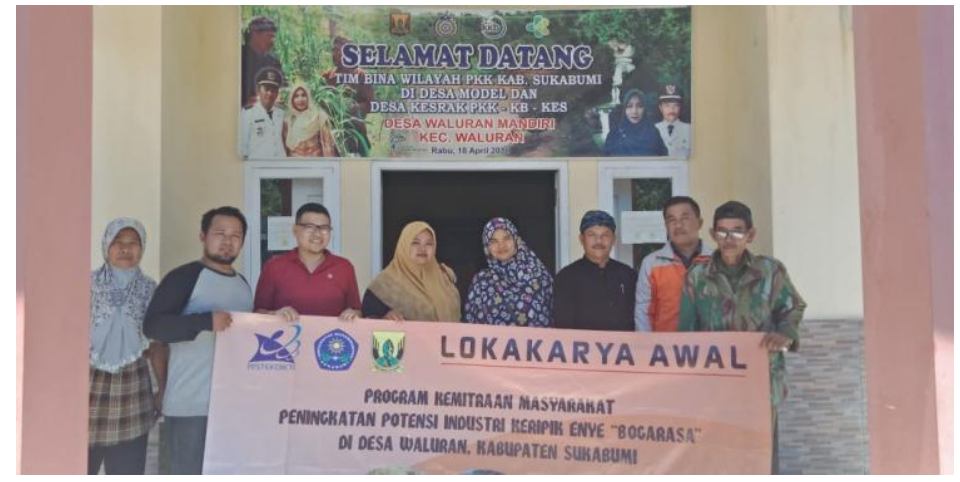

(b) Bersama para kelompok tani "Bogarasa", perwakilan masyarakat dan aparatur Desa Waluran Mandiri 


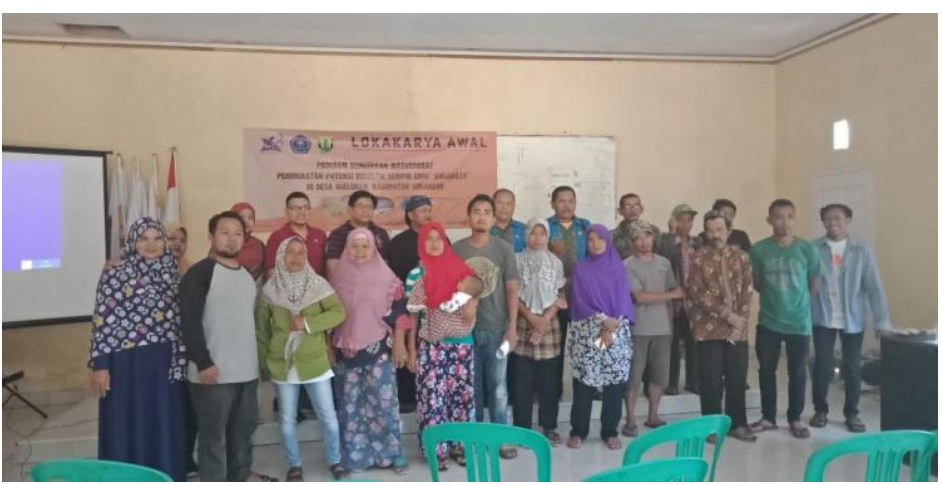

(c) Penutupan Kegiatan Lokakarya

Gambar 4. Lokakarya Kegiatan PKM Peningkatan Potensi Industri "Keripik Enye" Waluran.

\section{Brainstorming Merek Produk dan Kemasan}

Pada kegiatan ini dilakukan dengan kelompok Tani "BOGARASA" mengenai masukan dan saran merek produk yang diusulkan. Beberapa merek yang diusulkan antara lain:

a. Enye Emak Opik yang didasarkan pada tokoh fenomenal dengan konsep "Segala sesuatu yang besar dulunya kecil"

b. Enye Blue Pink yang agak sedikit dengan K-Pop

c. Enye Boa Uenak, dengan jargon daripada Boa Edan mending Boa Uenak

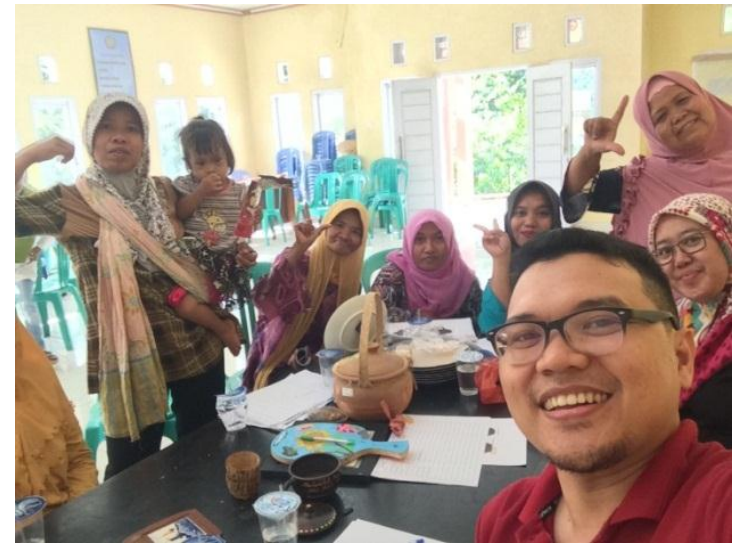

Gambar 5. Kegiatan Brainstorming dengan masyarakat Desa

\section{Brainstorming Prototyping Produk}

Dalam kegiatan ini dilakukan perencanaan untuk inovasi produk. Kegiatan dilakukan dengan eksperimen pembuatan "Keripik Enye" yang mengubah dari segi ketebalan, ukuran, eksperimen bumbu penyedap. Untuk dimensi "Keripik Enye", semula berukuran diameter $5 \mathrm{~cm}$ akan diperkecil menjadi 2,5 cm. Hal ini bertujuan agar "Keripik Enye" menempati seluruh ruang kemasan, dan meminimalisir rongga-rongga yang tidak terisi. Seperti yang terlihat pada gambar 3 di bawah ini: 


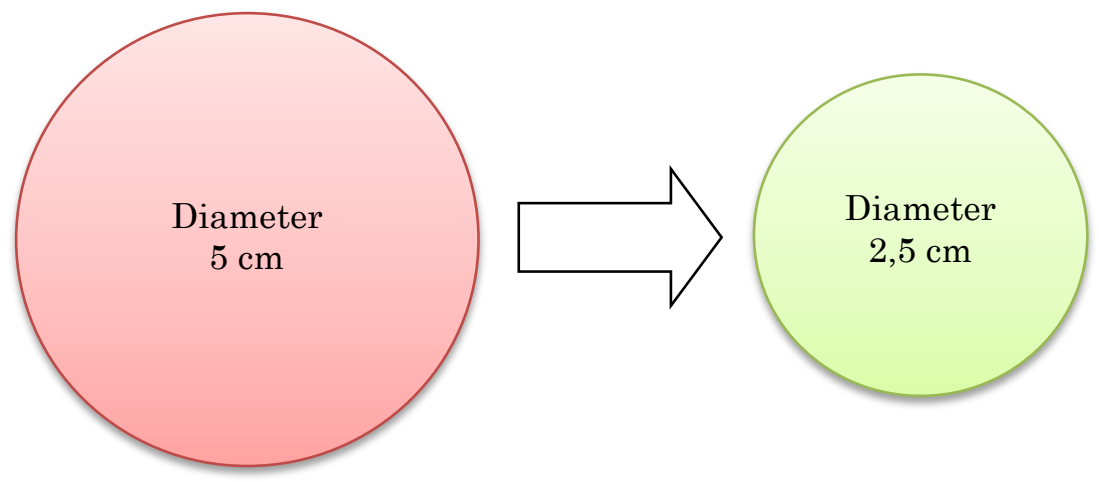

Gambar 6. Dimensi Ukuran "Keripik Enye"

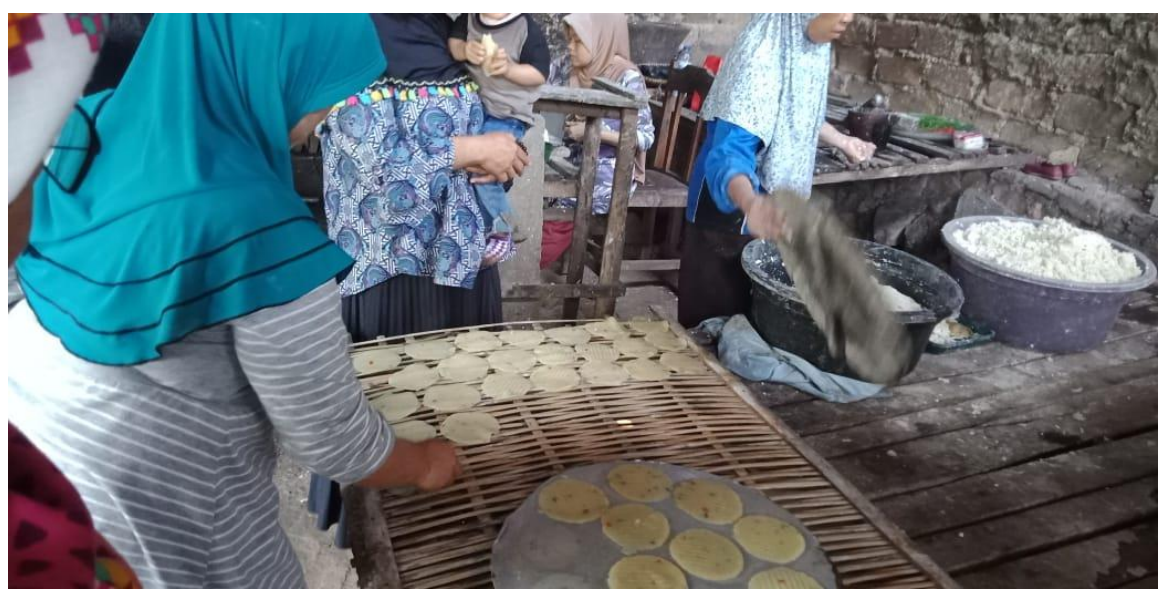

Gambar 7. Proses Pembuatan "Keripik Enye” dengan Modifikasi

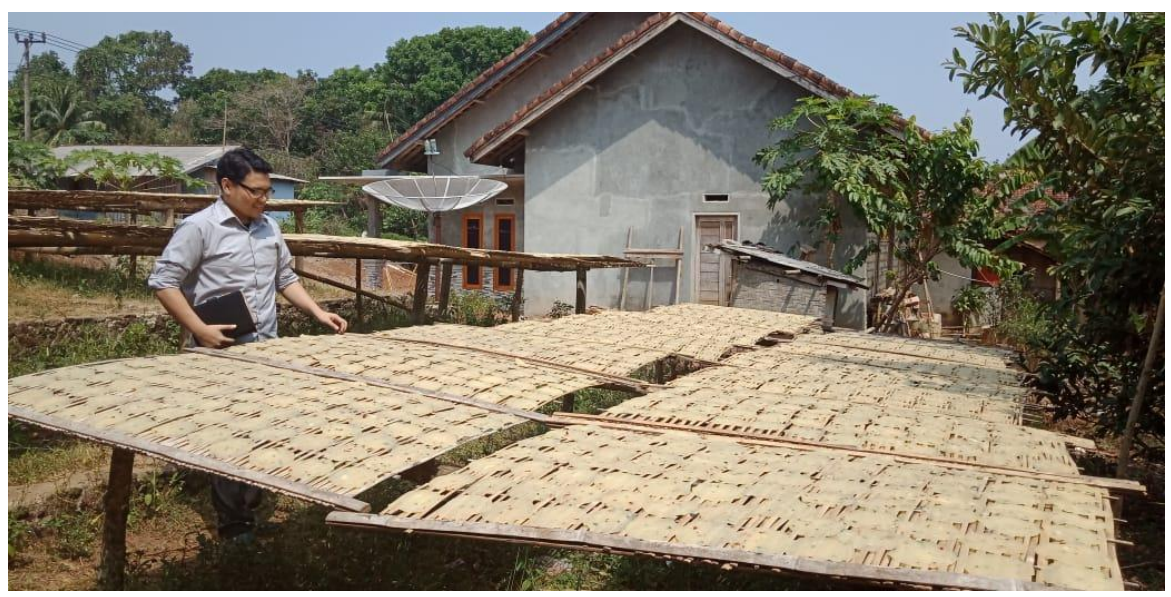

Gambar 8. Proses Penjemuran "Keripik Enye” Menggunakan Bambu

Adapun untuk mempercepat pengeringan "Keripik Enye" dimana semula loyang yang digunakan adalah menggunakan bambu, lalu dimodifikasi menggunakan baja tahan karat (Stainless steel). Setelah dilakukan modifikasi loyang, proses penjemuran yang semula dengan bambu dilakukan selama 6 jam, setelah dimodifikasi menggunakan stainless steel maka penjemuran lebih singkat yakni 3 jam. Hasil penjemuran lebih kering dan ketika digoreng rasa yang dihasilkan lebih renyah. Untuk varian rasa terdiri dari: (1) Original, (2) Pedas Manis, (3) Sapi Panggang / Barbeque 


\section{Pelatihan Penjualan dengan media Online}

Promosi dan penjualan melalui media sosial dilakukan melalui Instagram dan Youtube. Untuk akun instagram menggunakan akun bisnis dengan nama @KeripikEnyeWaluran. Konten yang ada di dalamnya berisi varian rasa "Keripik Enye", profil singkat "Keripik Enye", testimoni dari penggemar "Keripik Enye".

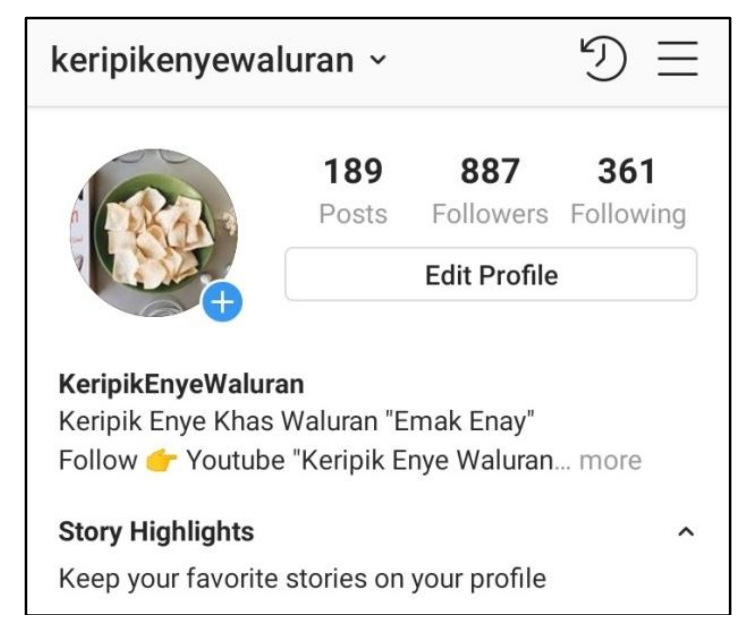

Gambar 9. Tampilan Akun Instagram @KeripikEnyeWaluran

Adapun akun YouTube yang dibuat dengan nama "Keripik Enye Waluran Emak Enay", yang di dalamnya berisi beberapa vlog testimoni youtubers lokal dan profil "Keripik Enye" waluran emak enay.

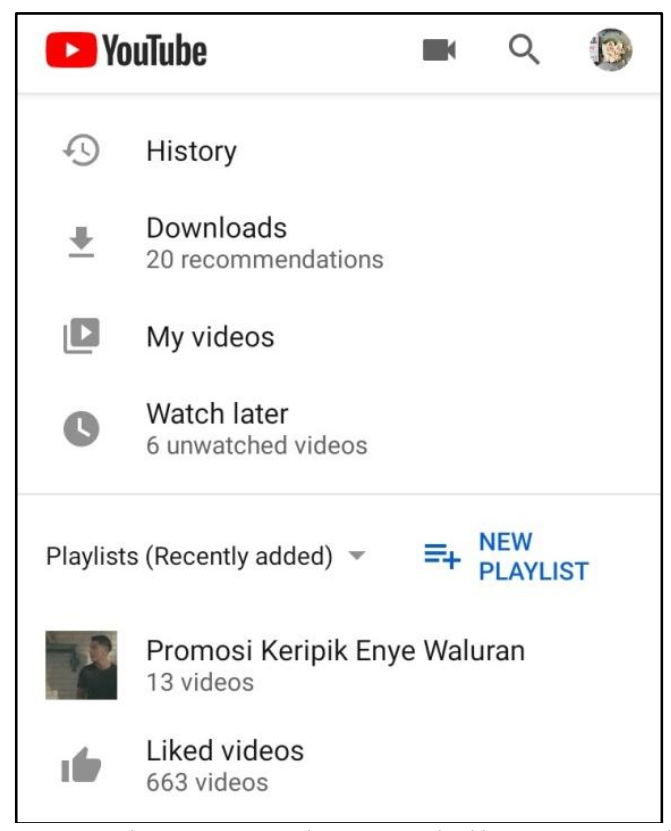

Gambar 10. Tampilan Akun Youtube "Keripik Enye Waluran Emak Enay"

5. Pendampingan Pengurusan Perizinan Industri Rumah Tangga (P-IRT)

Pendampingan dilakukan dengan pengujian produk di Labkesda Kabupaten Sukabumi, yang terdiri dari pengujian nilai gizi makanan dan pengujian kelayakan makanan untuk dikonsumsi. Hasil dari pengujian ini adalah nilai gizi dan layak untuk dikonsumsi. 


\section{SIMPULAN DAN SARAN}

Inovasi dalam pengembangan produk perlu dilakukan seperti halnya "Keripik Enye" waluran, dimana dilakukan inovasi produk yakni branding, packaging, dan penambahan varian rasa. Setelah dilakukan inovasi produk tersebut, terjadi peningkatan penjualan dan masyarakat lebih mengetahui produk lokal yang menjadi potensi di kawasan wisata Geopark Ciletuh. Hal ini berdampak pada peningkatan perekonomian masyarakat yang menunjang pada kesejahteraan masyarakat, khususnya di Desa Waluran Mandiri. Adapun saran untuk keberlanjutan adalah perlunya survey masyarakat mengenai rasa, bentuk dan ukuran. Sehingga produk bervariasi dan meningkatkan pendapatan masyarakat. Juga terus-menerus mengupdate konten media sosial Instagram dan YouTube, agar "Keripik Enye" Waluran dapat terus dikenal oleh masyarakat

\section{UCAPAN TERIMA KASIH}

Tim penulis mengucapkan terima kasih kepada Kementerian Riset Teknologi dan Pendidikan Tinggi (Kemenristekdikti) melalui Hibah Pengabdian Masyarakat untuk Skim Program Kemitraan Masyarakat (PKM), juga kepada Lembaga Penelitian dan Pengabdian Masyarakat Universitas Muhammadiyah Sukabumi (LPPM-UMMI) yang sudah memfasilitasi dalam kelancaran kegiatan ini, serta seluruh masyarakat dan aparatur Desa Waluran Mandiri Kabupaten Sukabumi.

\section{DAFTAR RUJUKAN}

[1] Badan Pusat Statistik Sukabumi. (2017). Waluran Dalam Angka. BPS, Sukabumi

[2] Hanifah, Vyta W., D. Yulistiani, S. A. A. Asmarasari. (2010). Optimalisasi Pemanfaatan Limbah Kulit Singkong menjadi Pakan Ternak dalam Rangka Memberdayakan Pelaku Usaha Enye-enye. Bogor: Teknologi Peternakan dan Veteriner. Seminar Nasional (550-556)

[3] Koswara, Sutrisno. (2009). Pengolahan Aneka Kerupuk. Bogor: Institut Pertanian Bogor

[4] Nugraha, Setia. (2014). Kota Sukabumi dari Distrik menjadi Gementee (1815 1914). Jurnal Patanjala 9(3), hh. 423-438

[5] https://www.bps.sukabumikab.go.id/ 